16. "On some Superficial Deposits in the Neighbourhood of Eresham." By the Rev. A. H. Winnington Ingram, M.A., F.G.S.

The lower series of gravels on Green Hill contains unworn flints about 10lbs. in weight. They are about 120 feet above the level of the Aron, and were probably brought by floating-ice. A clay at Bengeworth, beneath a sand with Unio ovalis (60 feet above the Avon), has yielded entire heads and horns of Bos primigenius, Bison priscus, an antler of Cervus tarandus, and a tooth of Hippopotamus, with other mammalian bones. A similar clay on the opposite side of the river at Evesham has furnished Cervus tarandus and river-shells, etc.

17. "Descriptions of Palæozoic Corals from Northern Queensland, with Observations on the Genus Steriopora." By Prof. H. A. Nicholson, M.D., D.Sc., F.G.S., and R. Etheridge, Esq., Jun., F.G.S.

The Corals described in this paper were in part collected by the late Mr. Daintree, ehiefly from the limestone of the Broken River, regarded as of Devonian age, and in part by Mr. R. L. Juck from various sources, namely, the Bowen-river Coalfield, in beds probably of Permo-Carboniferous age, the Fanning-river Limestone (Devonian), and the Arthur'screek Limestone (Permo-Carboniferous). Mr. Daintree's collection also contained corals in the chloritic rock of the Gympsie Goldfield. From the Coral Creek, Bowen-river Coalfield, the authors record Stenopora ovata, Lonsd., and S. Jackii, sp. n.; from the Fanning-river Limestone, Heliolites porosus, Goldf., and Pachypora meridionalis, sp. n.; from the Gympsie chloritic rock Stenopora ?sp. ind.; from the Brokenriver Limestone, Favosites gothlandicus, vars. Lam., Heliolites porosus, Goldf., $\boldsymbol{H}$. plasmoporoides, sp. n., H. Daintreei, sp. n., Heliolites sp. ind., and Araopora australis, sp. n.; from the Arthur's-creek Limestone, Burdekin Down, Alveolites (Pachypora?), sp., near A. robustus, Rom., Alveolites sp. (lobate form), Aulopora repens, M.-Edw. \& H., Heliolites porosus, Goldf., and vars., Lithostrotion sp. ind., Pachypora meridionalis, Trachypora sp. ind., and species of Cannopora and Stromatopora. The genus Araopora is proposed as a new group; the genus Stenopora is made the subject of a long discussion; and the geological characters of the deposits from which the fossils are derived are indicated and discussed.

The Socretr then adjourned to November $5 t h$.

COREFSPONDEINOE.

LENTICULAR HILLS OF GLACIAL DRIFT.

Sir,-In the June Number of the Geological Magazine Mr. Warren Upham asks whether British geologists have noted accumulations of Till like the "lenticular hills" of Prof. Hitchcock. The description given of these hills answers precisely to that given by Messrs. Kiuahan and Close, in their paper on the "General Glaciation of Yar-Connaught," of the "drum-lines" of unstratified Boulder-clay.

Mr. James Geikie, also, in his "Great Ice Age," says that "in lowland tracts the till is frequently arranged in long round-backed 
ridges, which are parallel to one another and to the direction of the principal valley of the district."

Similar mounds are equally common in many parts of the Yorkshire dales : they occur, for instance, in Bishopsdale, Wensleydale, and Ribblesdale, and on the Haws between the latter dale and Wharfdale. In Westmorland, too, such mounds are common at the foot of the mountains, and they form a striking feature in the landscape of the low ground near Kendal. J. R. Dakyns.

Bridlington Quat.

\section{FAULTS IN THE LONDON CLAY, NEAR HARWICH.}

SIR,-The extensive excavations now going on at Ray Island, near Harwich, where the new docks are being constructed for the Great Eastern Railway Company, have exposed some splendid banded sections of the London Clay. One of these is plainly visible to the railway traveller, on the left-hand side, about a mile before he reaches Dovercourt Station. As nearly the whole of the humpy mass of land now called Ray Island is intended to be carried into the neighbouring estuary of the Stour for the erection of embankments, a notice of the dislocations now visible in the sections is of geological value.

In many places the London Clay is seen to be thrown into a series of very gentle folds. At no fewer than nine places in the section, small faults are as plainly visible as in a geological diagram, owing to the banded character of the strata. With one exception all the faults have an angle of about fifty degrees, the exceptional fault (seen in the railway cutting) being nearly vertical. The latter shows a dislocation of about two feet. The largest fault is visible in that end of the railway cutting nearest to Dovercourt, and measures upwards of twelve feet. A fault of more than eight feet is seen in a section near the estuary, and some of the minor dislocations occur at intervals of from fifty to one hundred yards. The line of fault is in most instances as sharply defined as if the strata had been diagonally cut through with a knife.

J. E. TAYLOR.

\section{PYRITIFEROUS SAND FROM LAKE WINNIPEG.}

SIR,-I have had a sample of somewhat curious sand put in my hands by a man who has recently returned from America, and venture to think it may elicit some further information about it could you find space for my note. I send a sample of the sand; you will see that it consists of a very fine grained siliceous sand, grey in colour, the greyness being due to an innumerable quantity of almost microscopic concretions of pyrites. Under the microscope these are pretty objects, mostly globular, and when broken show very distinctly their concentric structure; they appear very similar on a minute scale to the concretions so commonly met with in the Cretaceous deposits, etc. Possibly they have formed round a foraminiferous or other organic nucleus, but I have not succeeded in detecting it as yet in any of the broken glubules.

The locality from which the sand was brought is said to be on the 